\title{
Planowanie w samorządzie terytorialnym Wybrane problemy prawne
}

\author{
Katarzyna Wlaźlak \\ Dr, Uniwersytet Łódzki, Wydział Prawa i Administracji, \\ Katedra Prawa Administracyjnego i Nauki Administracji \\ http://dx.doi.org/10.18778/8088-114-3.08
}

\section{Wprowadzenie}

Problemy samorządu terytorialnego, rozpatrywane z perspektywy 25 lat jego istnienia, nie pozostawiają wątpliwości co do istotnego znaczenia prawa dla prawotwórczej i wykonawczej działalności administracji samorządowej. Wśród wielu ważnych problemów pojawiających się w teorii i praktyce wyodrębnić można problemy szerzej pojmowanego planowania. Po reaktywowaniu samorządu terytorialnego w 1990 r. prawny model planowania nie charakteryzował się jeszcze tak dużą pojemnością i niestabilnością. W kolejnych latach, szczególnie po rozbudowie struktur samorządu na poziomie powiatu i województwa w 1998 r., planowanie stopniowo nabierało większego znaczenia, a po akcesji Polski do Unii Europejskiej bardzo dynamicznie już obejmowało kolejne obszary prawa. Nie ustają tendencje prawodawcy do zwiększania roli planowania w działalności samorządu terytorialnego, w efekcie ta problematyka nabiera coraz donioślejszego znaczenia w praktyce.

Współczesny model planowania rozproszony jest w wielu aktach dotyczących funkcjonowania samorządu terytorialnego, o różnej mocy prawnej, w prawie ustrojowym, materialnym, proceduralnym. Zorientowany na przyszłość, prospektywny i cykliczny charakter planowania powoduje, że jego prawna regulacja jest w dużej mierze ogólna, fragmentaryczna, a do tego zmienna. Słusznie podkreśla się, że funkcja planowania - w porównaniu $\mathrm{z}$ innymi funkcjami administracji - ma najmniej jasne i stabilne podstawy prawne ${ }^{1}$. Prawodawca $\mathrm{w}$ zasadzie pozostawia organom

1 B. Popowska, Klasyfikacja funkcji administracji w nauce publicznego prawa gospodarczego, [w:] Funkcje wspótczesnej administracji gospodarczej. Księga dedykowana Profesor Teresie Rabskiej, red. B. Popowska, Poznań 2006, s. 84. 
jednostek samorządu terytorialnego możliwość swobodnego planowania, zapewnia zdolność do zmiany celów, zadań, a nawet instrumentów ich realizacji w razie zmiany warunków podczas wykonywania poszczególnych elementów procesu planowania ${ }^{2}$. Nie jest wobec tego łatwe porządkujące i systemowe ujęcie problematyki planowania w samorządzie terytorialnym. Poza rozległym zakresem unormowań, charakterystyczne są różnorodne formy aktów planowania oraz ich niejednorodne cechy prawne.

\section{Kwestia terminologii}

Niejednolita i specyficzna jest terminologia odnosząca się do aktów planowania, rodząca w praktyce różne i liczne problemy. Na gruncie obowiązującego prawa samorządu terytorialnego występują m.in. plany (np. miejscowy plan zagospodarowania przestrzennego, plany zrównoważonego rozwoju publicznego transportu zbiorowego jednostek samorządu terytorialnego i ich związków, wojewódzki plan działań na rzecz zatrudnienia), strategie (np. strategia rozwiązywania problemów społecznych, strategie rozwoju), programy (np. z zakresu ochrony środowiska, programy operacyjne, programy działań), budżety jednostek samorządu terytorialnego i ich związków, wieloletnie prognozy finansowe, studium uwarunkowań i kierunków zagospodarowania przestrzennego gminy, koncepcje, analizy i studia (z zakresu zagospodarowania przestrzennego), Priorytety współpracy zagranicznej województwa, kierunki działania wójta/burmistrza/prezydenta miasta oraz kierunki działania zarządu powiatu, wytyczne programowe województwa, dokumenty programowe (umowa partnerstwa i programy służące jej realizacji) i inne.

Trzeba zwrócić uwagę, że wiele $\mathrm{z}$ tych pojęć jest wieloznacznych (np. koncepcja, analizy, priorytety, kierunki), a jednocześnie ustawowo niesprecyzowanych. D.R. Kijowski uważa, że ustalenie precyzyjnych definicji różnych pojęć nie jest $\mathrm{w}$ tym przypadku niezbędne, bo żadne $\mathrm{z}$ nich nie posiada ściśle wyznaczonego prawem zakresu znaczeniowego. Analiza przepisów ustawowych wskazujących co ma być w danym - tak czy inaczej nazwanym - akcie zawarte, pozwala na uchwycenie, że praktycznie zawsze ma to być spis zamiarów, które podmioty go tworzące zamierzają w przyszłości zrealizować, najczęściej w wyznaczonym w tym akcie cza-

2 Zob. K. Strzyczkowski, Administracyjnoprawne instytucje planowania, Warszawa 1985, s. 10. 
sie $^{3}$. Z tym nie sposób się nie zgodzić. Zgłaszane w piśmiennictwie różne propozycje określania aktów planowania, w tym aktami polityki (administracyjnej $)^{4}$, traktowane są $\mathrm{w}$ kategoriach jedynie pewnej konwencji. Najczęściej spotykanymi pojęciami są akt planowania (planistyczny) lub - tradycyjnie już używane - plan, przy czym występują one jako pojęcia zbiorcze, wspólne dla tej kategorii aktów, ustawowo niejednolicie nazywanych ${ }^{5}$. Na przykład M. Stahl podkreśla, że termin „akty polityki” lepiej oddaje istotę i zróżnicowanie planów, chociaż jest tylko umowną kategorią, bo akty polityki są zarazem aktami planowania ${ }^{6}$. Z kolei M. Kulesza rozumiał plan jako wyraz swoistego kompromisu między tym, co niezbędne a tym, co możliwe, jako wiążące akty polityki i zarazem narzędzie koordynacji ${ }^{7}$.

$\mathrm{Na}$ tle specyficznej terminologii pojawiają się jednak różne wątpliwości, zwłaszcza że prawodawca pozostaje nieraz przy tych określeniach niekonsekwentny. Są przykłady używania odmiennych nazw dla tego samego aktu, np. jednym razem „powiatowy program przeciwdziałania bezrobociu oraz aktywizacji lokalnego rynku pracy" (art. 12 pkt 9c ustawy z dnia 5 czerwca 1998 r. o samorządzie powiatowym ${ }^{8}$ ), innym - „program promocji zatrudnienia oraz aktywizacji lokalnego rynku pracy" (art. 9 ust. 1 pkt oraz ust. 2 ustawy z dnia 20 kwietnia 2004 r. o promocji zatrudnienia i instytucjach rynku pracy ${ }^{9}$ ). Nawet na gruncie jednej tylko ustawy przygotowywany jest projekt „powiatowego programu zapobiegania przestępczości oraz porządku publicznego i bezpieczeństwa obywateli”

3 D.R. Kijowski, Programy, plany i strategie jako podstawa działań organów administracji publicznej, [w:] Wpływ przemian cywilizacyjnych na prawo administracyjne i administrację publicznq, red. J. Zimmermann, P.J. Suwaj, Warszawa 2013, s. 246.

4 M. Kulesza, Administracyjnoprawne uwarunkowania polityki przestrzennej, Warszawa 1987, s. 208-213; J. Jeżewski, Polityka administracyjna. Zagadnienia podstawowe, [w:] A. Błaś, J. Boć, J. Jeżewski, Administracja publiczna, Wrocław 2003, s. 316 i n.; I. Skrzydło-Niżnik, Model ustroju samorzqdu terytorialnego w Polsce na tle zagadnień ustrojowego prawa administracyjnego, Kraków 2007, s. 533; K. Wlaźlak, Charakter prawny aktów planowania i ich rola w realizacji zadań administracji publicznej, „Przegląd Prawa Publicznego” 2009, nr 6, s. 26; L. Bielecki, Prawne formy i metody działania administracji, [w:] Prawo administracyjne. Część ogólna, red. L. Bielecki, P. Ruczkowski, Warszawa 2011, s. 358; E. Olejniczak-Szałowska, Tworzenie planów, programów i strategii, [w:] Prawo administracyjne. Pojęcia, instytucje, zasady w teorii i orzecznictwie, red. M. Stahl, Warszawa 2013, s. 494.

5 Zob. E. Ochendowski, Prawo administracyjne. Część ogólna, Toruń 2013, s. 148 i n.; J. Zimmermann, Prawo administracyjne, Warszawa 2014, s. 108.

6 M. Stahl, Szczególne prawne formy działania administracji, [w:] System prawa administracyjnego. Tom 5. Prawne formy działania administracji, red. R. Hauser, Z. Niewiadomski, A. Wróbel, Warszawa 2013, s. 371.

7 M. Kulesza, Administracyjnoprawne uwarunkowania..., s. 204.

8 Tekst jedn. Dz.U. z 2013 r., poz. 595 ze zm.

9 Tekst jedn. Dz.U. z 2015 r., poz. 149 ze zm. 
(art. 38a ust. 2 pkt 3 ustawy o samorządzie powiatowym), a uchwalany „powiatowy program zapobiegania przestępczości oraz ochrony bezpieczeństwa obywateli i porządku publicznego" (art. 12 pkt 9b ustawy o samorządzie powiatowym). Niektóre ustawowe pojęcia, jak „krajowa polityka miejska" (rozdział 3a ustawy z dnia 6 grudnia 2006 r. o zasadach prowadzenia polityki rozwoju ${ }^{10}$ ), są szczególnie kontrowersyjne, bo nie odpowiadają aktualnym warunkom ustrojowym, uniemożliwiając przyporządkowanie planu do struktury organizacyjnej, w której ten akt ma być tworzony i realizowany.

Nie istnieje żaden uporządkowany system pojęć, samorządowe akty planowania charakteryzują się ponadto niezwykle rozbudowanymi, poziomymi i pionowymi relacjami. Nieraz są w różny sposób powiązane z planami innych podmiotów administrujących, przybierającymi (poza wskazanymi wyżej) specyficzne nazwy i formy, jak założenia, oceny, raporty, projekty, podstawy, polityki, ramy, perspektywy, efekty i inne. $\mathrm{Na}$ przykład polityka ochrony środowiska prowadzona jest na podstawie strategii rozwoju, programów i dokumentów programowych, o których mowa w ustawie o zasadach prowadzenia polityki rozwoju, a także za pomocą wojewódzkich, powiatowych i gminnych programów ochrony środowiska (tytuł I, dział III ustawy z dnia 27 kwietnia 2001 r. - Prawo ochrony środowiska $\left.{ }^{11}\right)$. W doktrynie katalog samorządowych aktów planowania nie jest zamknięty. Bywają do nich zaliczane takie specyficzne kategorie jak akty intencyjne, np. uchwały, w których rady gmin wyrażają zamiar likwidacji szkoły ${ }^{12}$. Rzadziej za plany uznaje się statuty i regulaminy samorządowe ${ }^{13}$ oraz sprawozdania ${ }^{14}$.

Nawet na gruncie jednej ustawy występują niejednakowo określane, bardzo złożone formy planowania. Zjawisko to trafnie oddaje termin „wieloprogramowe planowanie strategiczne” ${ }^{15}$. Nie brakuje aktów planowania zawierających kilka charakterystycznych pojęć dla jednego aktu, np. studium uwarunkowań i kierunków zagospodarowania przestrzennego gminy, programy polityki zdrowotnej, wytyczne programowe województwa. Pod tym względem nie jest również łatwo odróżnić od siebie wielu planów, o których mowa w bezpośrednio wiążących normach prawa Unii Europejskiej, np. Strategiczne Wytyczne Wspólnoty (Community Strategic Guidelines), Narodowe Strategiczne Ramy Odniesienia (Natio-

10 Tekst jedn. Dz.U. z 2014 r., poz. 1649 ze zm.

11 Tekst jedn. Dz.U. z 2013 r., poz. 1232 ze zm.

12 D. Dąbek, Prawo miejscowe, Warszawa 2015, s. 155.

13 Tak: T. Dziurbejko, Planowanie rozwoju gminy jako instrument pozyskiwania funduszy pomocowych Unii Europejskiej, Warszawa 2006, s. 69.

14 Tak: J. Zimmermann, Aksjomaty prawa administracyjnego, Warszawa 2013, s. 183.

15 Tak: A. Jaxa Dębicka, Sprawne państwo. Wspótczesne koncepcje i instrumenty zarzq̨dzania publicznego a administracja publiczna, Warszawa 2008, s. 252. 
nal Strategic Reference Framework). Podobnie skomplikowana terminologia charakteryzuje prawo wewnętrzne państw członkowskich, np. belgijskie strategiczne plany bezpieczeństwa (strategic plan of security). Przy wielowymiarowych powiązaniach aktów planowania, w tym będących efektem transpozycji aktów prawa UE do polskiego porządku prawnego, niejasna pozostaje kwestia ogólności planów.

W ramach strategii albo planu mogą być przyjmowane programy (np. w zakresie polityki rozwoju społeczno-gospodarczego, pomocy społecznej, promocji zatrudnienia), bywają jednak w programie albo w koncepcji uwzględniane plany (np. w gospodarce odpadami, w zagospodarowaniu przestrzennym). Jedne plany włączane są w ramy innych, nierzadko odmiennie określanych, np. w studium uwarunkowań i kierunków zagospodarowania przestrzennego gmin oraz $\mathrm{w}$ miejscowych planach zagospodarowania przestrzennego ustalane są programy racjonalnego wykorzystania powierzchni ziemi (art. 72 ust. 1 pkt 1 ustawy - Prawo ochrony środowiska), plan inwestycyjny stanowi załącznik do wojewódzkiego planu gospodarki odpadami (art. 35a ust. 4 ustawy z dnia 14 grudnia 2012 r. o odpadach $^{16}$ ), program ochrony i zrównoważonego użytkowania różnorodności biologicznej uchwalany jest wraz z planem działań (art. 111 ust. 3 ustawy $z$ dnia 16 kwietnia 2004 r. o ochronie przyrody ${ }^{17}$ ), a plan znakowania zwierząt w gminie stanowi fakultatywną część programu opieki nad zwierzętami bezdomnymi oraz zapobiegania bezdomności zwierząt (art. 11a ust. 3 ustawy z dnia 21 sierpnia 1997 r. o ochronie zwierzą $\left.{ }^{18}\right)$.

Poszczególne plany często są tworzone $\mathrm{z}$ uwzględnieniem ustaleń zawartych $\mathrm{w}$ innych - różnie określanych - planach. Pojawiły się np. wątpliwości dotyczące istoty programów gospodarczych uchwalanych na podstawie art. 18 ust. 2 pkt 6 ustawy z dnia 8 marca 1990 r. o samorządzie gminnym ${ }^{19}$. Ani zakres przedmiotowy programu, ani okres jego obowiązywania nie są w ustawie ustalone. Powstaje pytanie, czy można utożsamiać taki program ze strategią rozwoju gminy ${ }^{20}$, czy raczej należałoby przyjąć, że jego charakter jest specjalistyczny i stanowi pewną formę konkretyzacji gminnej strategii rozwoju, odnosząc się każdorazowo do różnych określonych w niej problemów ${ }^{21}$. Wydaje się, że o ile uchwała w sprawie strategii rozwoju gminy powinna zasadzać się na problemach bardziej strategicznego i szerzej pojmowanego rozwoju lokalnego, o tyle

16 Tekst jedn. Dz.U. z 2013 r., poz. 21 ze zm.

17 Tekst jedn. Dz.U. z 2013 r., poz. 627 ze zm.

18 Tekst jedn. Dz.U. z 2013 r., poz. 856 ze zm.

19 Tekst jedn. Dz.U. z 2013 r., poz. 594 ze zm.

20 Tak: A. Szewc, Władze gminy, [w:] A. Szewc, G. Jyż, Z. Pławecki, Ustawa o samorzq̨dzie gminnym. Komentarz, Warszawa 2012, s. 242.

21 Tak: K. Wlaźlak, Komentarz do art. 18, [w:] Ustawa o samorzqdzie gminnym. Komentarz, red. P. Chmielnicki, Warszawa 2013, s. 367. 
dla uchwały w sprawie programu gospodarczego właściwe są zagadnienia natury inwestycyjnej czy branżowej, dotyczące konkretnego elementu rozwoju gospodarczego gminy. Dla danego okresu przyjmowana jest jedna strategia rozwoju gminy, natomiast określenie „uchwalanie programów gospodarczych" pozwala stwierdzić, że rada gminy może uchwalić co najmniej kilka takich programów.

Programy gospodarcze są swego rodzaju planami zamierzeń gminy w sferze gospodarczej, zawierającymi także zasady lokalnej polityki gospodarczej i społecznej, a ich uchwalanie powinny poprzedzać analizy i oceny mechanizmów gospodarki rynkowej na terenie gminy ${ }^{22}$. Trafnie podniósł WSA w Gliwicach w wyroku z dnia 8 maja $2008 \mathrm{r}^{23}$, że programy gospodarcze są planami rozwojowymi, mają charakter ogólny, ale obejmują założenia co do danego przedsięwzięcia. Nie można ponadto powielać w uchwale podjętej w trybie art. 18 ust. 2 pkt 6 ustawy o samorządzie gminnym postanowień podlegających regulacjom uchwały budżetowej. W oparciu o ten przepis może być uzasadnione wprowadzenie innej nazwy niż „program”. Taki pogląd wyraził WSA w Gdańsku w wyroku z dnia 2 maja $2007 \mathrm{r}^{24}$ dopuszczając uchwalenie w tym trybie planu odnowy wsi.

\section{Status prawny aktów planowania}

Cechy prawne wielu aktów planowania są nie tylko niejednolite, ale i odmiennie postrzegane, a często rodzące różnorodne pytania w literaturze oraz orzecznictwie. Sam status prawny wielu planów jednostek samorządu terytorialnego nie jest łatwy do ustalenia. Tylko nieliczne $\mathrm{z}$ nich mają ustawowo sprecyzowany charakter, $\mathrm{w}$ tym miejscowy plan zagospodarowania przestrzennego oraz studium uwarunkowań i kierunków zagospodarowania przestrzennego gminy (art. 14 ust. $8 \mathrm{i}$ art. 9 ust. 5 ustawy z dnia 27 marca 2003 r. o planowaniu i zagospodarowaniu przestrzennym ${ }^{25}$ ), plan zrównoważonego rozwoju publicznego transportu zbiorowego (art. 9 ust. 3 ustawy z dnia 16 grudnia 2010 r. o publicznym transporcie zbiorowym ${ }^{26}$ ), programy mające na celu doprowadzenie do przestrze-

22 Z. Leoński, Samorząd terytorialny w RP, Warszawa 2006, s. 54.

23 III SA GI 399/08, CBOSA.

24 II SA/Gd 715/06, LEX nr 929903.

25 Tekst jedn. Dz.U. z 2015 r., poz. 199 ze zm.

26 Dz.U. z 2011 r. Nr 5, poz. 13 ze zm. 
gania standardów jakości środowiska (art. 84 ustawy - Prawo ochrony środowiska), które są uchwalane wraz ze stwierdzeniem naruszenia tych standardów, w przypadkach określonych ustawą lub w przepisach szczególnych (program ochrony powietrza przed zanieczyszczeniem wprowadzany uchwałą sejmiku województwa ${ }^{27}$, program ochrony przed hałasem uchwalany przez radę powiatu lub sejmik województwa ${ }^{28}$ ).

W innych przypadkach przepisy ustawy nie wskazują wprost na obowiązywanie aktów planowania ani erga omnes, ani nawet na ich wewnętrzny charakter, a specyficzna treść tych aktów - w większym lub mniejszym zakresie określona już $\mathrm{w}$ ustawie - sprawia, że niezwykle trudno jest odróżnić plany - akty kierownictwa wewnętrznego od tych, które bezpośrednio rzutują na sytuację prawną obywateli. Nawet wyprowadzanie charakteru prawnego aktu planowania w drodze pełnego katalogu metod wykładni nie zawsze prowadzi do jednoznacznych wniosków w tej kwestii. Nie należą do wyjątków plany, których postanowienia $\mathrm{w}$ istocie wywołują różnorodne skutki, nie zawsze ograniczając się do sytuacji prawnej podmiotów z samorządowej struktury organizacyjnej, w ramach której dany plan został ustanowiony. Bardzo często względny jest charakter podziału postanowień planów na imperatywne (nakazujące, prawnie wiążące), influencyjne (odziaływujące, wpływające, pośrednio kreujące sytuację prawną adresatów) i indykatywne (oznajmiające, spełniające jedynie funkcję informacyjną).

Wątpliwości nasuwają chociażby przepisy ustawy z dnia 10 kwietnia 1997 r. - Prawo energetyczne ${ }^{29}$, na podstawie których uchwalane są plany gminne w obszarze energetyki. Plany lub założenia do planu zaopatrzenia w ciepło, energię elektryczną i paliwa gazowe bywają zaliczane do - obok miejscowych planów zagospodarowania przestrzennego - grupy uchwał o charakterze programowym będących zarazem źródłami prawa miejscowego ${ }^{30}$. Niektórzy autorzy dostrzegają zarówno indykatywne (informacyjne), influencyjne (motywujące), jak i imperatywne (nakazowe) postanowienia planów w zakresie energetyki. Rola tych pierwszych ogranicza się do informowania o aktualnym stanie zapotrzebowania na nośniki energetyczne na obszarze gminy oraz opisywania przedsięwzięć racjonalizujących ich użytkowanie, wreszcie - wskazywania na możliwości wykorzystania istniejących nadwyżek i lokalnych zasobów paliw i energii. Postanowienia influencyjne to propozycja konkretnych przedsięwzięć inwestycyjnych w sferze infrastruktury energetycznej,

27 Art. 91 ustawy - Prawo ochrony środowiska.

28 Art. 119 ust. 1 ustawy - Prawo ochrony środowiska.

29 Tekst jedn. Dz.U. z 2012 r., poz. 1059 ze zm.

30 M. Kasiński, Monizm i pluralizm władzy lokalnej. Studium prawno-polityczne, Łódź 2009, s. 317. 
ze wskazaniem źródła finansowania tych inwestycji (przede wszystkim budżetu gminy). Postanowienia o takim charakterze znajdują się także w art. 20 ust. 5 ustawy - Prawo energetyczne stanowiącym, że w celu realizacji gminnego planu zaopatrzenia w ciepło, energię elektryczną i paliwa gazowe gmina może zawierać umowy z przedsiębiorstwami energetycznymi. Imperatywny natomiast - dla przedsiębiorstw energetycznych - charakter postanowień planów upatrywany jest w treści art. 20 ust. 6 ustawy - Prawo energetyczne, zgodnie z którym, gdy nie jest możliwa realizacja gminnego planu na podstawie umów, gmina może „wskazać w drodze uchwały tę część planu, z którą prowadzone na obszarze gminy działania muszą być zgodne"31.

Specyficzne pod tym względem są także uchwały budżetowe zaliczane do najważniejszych planów finansowych w jednostkach samorządu terytorialnego. Nie mieszczą się one bez reszty ani w grupie aktów politycznych należących do kategorii czynności faktycznych lub aktów prawa wewnętrznego, ani też w grupie aktów wykazujących cechy źródeł prawa miejscowego ${ }^{32}$. Większość przedstawicieli doktryny podziela pogląd prezentowany przez T. Dębowską-Romanowską, że akt budżetowy to szczególnego rodzaju akt planowania i zarządzania finansowego w okresie budżetowym, niewykazujący cech normatywnych w sensie materialno-prawnym i procesowym ${ }^{33}$. Można jednak spotkać odmienne stanowisko, zgodnie z którym uchwały budżetowe są szczególnymi i jednymi $z$ najważniejszych aktów prawa miejscowego ${ }^{34}$. Jest to dyskusyjne, biorąc pod uwagę, że podstawy prawne pobierania dochodów i realizowania wydatków wynikają nie $\mathrm{z}$ budżetu, a $\mathrm{z}$ innych aktów prawnych. Ujęcie w budżecie dochodów z określonych źródeł lub wydatków na określone cele nie stanowi podstawy prawnej roszczeń lub zobowiązań gminy wobec osób trzecich ani roszczeń tych osób wobec gminy $^{35}$. Nie pozostaje też bez znaczenia, że budżet może obowiązywać również z mocą wsteczną.

31 M. Szydło, Planowanie indykatywne jako funkcja państwa wobec gospodarki, [w:] Funkcje współczesnej administracji gospodarczej. Księga dedykowana Profesor Teresie Rabskiej, red. B. Popowska, Poznań 2006, s. 158-161.

32 M. Kasiński, Monizm i pluralizm..., s. 314.

33 T. Dębowska-Romanowska, Wybrane zagadnienia prawne aktów z zakresu spraw budżetowych - jako przedmiotu nadzoru regionalnych izb obrachunkowych, „Samorząd Terytorialny" 1994, nr 3, s. 22.

34 M. Zubik, Samorządowa uchwała budżetowa na tle ustrojowych zasad budżetowania. Wybrane problemy legislacyjno-prawne, „Przegląd Legislacyjny” 2003, nr 3, s. 21 i n.; wyrok NSA z dnia 7 listopada 1996 r., I SA/Po 1091/96, LEX nr 79745; uchwaty Regionalnej Izby Obrachunkowej w Koszalinie z dnia 27 lutego 1995 r., 34/95, LEX nr 43110 oraz z dnia 20 marca 1995 r., 45/95, LEX nr 42741.

35 P. Kryczko, Gminna gospodarka finansowa, [w:] Ustawa o samorządzie gminnym. Komentarz, red. P. Chmielnicki, Warszawa 2013, s. 718. 
Podobnie niejasna jest natura prawna wieloletniej prognozy finansowej. O jedynie planistycznym charakterze tego aktu świadczyć może dopuszczenie funkcjonowania jednostki samorządu terytorialnego bez tej prognozy w efekcie stwierdzenia jej nieważności. O ile bowiem regionalna izba obrachunkowa może stwierdzić nieważność takiej uchwały w przypadku jej sprzeczności z obowiązującym prawem, o tyle nie przysługuje - inaczej niż w razie nieuchwalenia budżetu samorządowego - prawo dokonywania ustaleń zastępczych. Stwierdzenie nieważności wieloletniej prognozy finansowej pociąga jednak za sobą stwierdzenie nieważności uchwały budżetowej jednostki samorządu terytorialnego, co wskazywałoby na prawnofinansowy charakter uchwały ${ }^{36}$.

Nadal kontrowersyjny pozostaje charakter regionalnego programu operacyjnego, w szczególności systemu realizacji, który jest elementem programu. Sądy administracyjne raz podnosiły, że systemy realizacji programów spełniają kryteria źródeł prawa w szerszym znaczeniu ${ }^{37}$, natomiast innym razem, że sam program regionalny nie jest nawet aktem prawnym, a wyłącznie dokumentem operacyjno-wdrożeniowym, tworzonym przez instytucję zarządzającą dla realizacji polityki rozwo$\mathrm{ju}^{38}$. Niektóre przepisy ustawy o zasadach prowadzenia polityki rozwoju zostały w tym zakresie uznane za niekonstytucyjne ${ }^{39}$ i częściowo zmienione. Dalej jednak system realizacji programu stanowi swoisty regulamin, którego przestrzeganie warunkuje uzyskanie dofinansowania przez wnioskodawców projektów. Regionalny program operacyjny jest przez to adresowany nie tylko do organów samorządu województwa, ale zachowuje też wpływ na prawa i obowiązki innych podmiotów aplikujących o uzyskanie pomocy finansowej. W art. 20 ust. 3 ustawy o zasadach prowadzenia polityki rozwoju sformułowany został jeszcze obowiązek ogłoszenia programu w wojewódzkim dzienniku urzędowym. Należy jednak zwrócić uwagę, że uchwałę w sprawie regionalnego programu operacyjnego podejmuje zarząd województwa, a więc organ bez kompetencji do stanowienia aktów prawa miejscowego.

W doktrynie i orzecznictwie niejednakowo określana była ponadto istota i prawne skutki wieloletnich programów gospodarowania mieszkaniowym zasobem gminy (uchwalanych na podstawie art. 21 ust. 1 pkt 1 ustawy z dnia 21 czerwca 2001 r. o ochronie praw lokatorów,

36 R.P. Krawczyk, Nadzór nad działalnościq samorzq̨du terytorialnego w Polsce aktualne problemy, [w:] Regiony w prawie i praktyce. Polska - Ukraina, red. K. Skotnicki, K. Wlaźlak, Łódź 2015, s. 127.

37 Wyrok NSA z dnia 1 grudnia 2011 r., II GSK 2232/11, LEX nr 1133563; wyrok NSA z dnia 18 maja 2011 r., II GSK 817/11, LEX nr 992441.

38 Postanowienie WSA w Łodzi z dnia 8 października 2010 r., II SA/Łd 973/10, LEX nr 773195.

39 Zob. wyrok TK z dnia 12 grudnia 2011 r., P 1/11, OTK 2011, z. 10, poz. 115. 
mieszkaniowym zasobie gminy i o zmianie Kodeksu cywilnego ${ }^{40}$ ), szczególnie w części dotyczącej zasad polityki czynszowej oraz warunków obniżania czynszu (art. 21 ust. 2 pkt 4); gminnego programu profilaktyki i rozwiązywania problemów alkoholowych (art. $4^{1}$ ust. 2 ustawy z dnia 26 października 1982 r. o wychowaniu w trzeźwości i przeciwdziałaniu alkoholizmowi ${ }^{41}$ ), zwłaszcza w części dotyczącej nakazu dostosowania liczby punktów sprzedaży oraz usytuowania miejsc sprzedaży, podawania i spożywania napojów alkoholowych do potrzeb ograniczania dostępności alkoholu, zawartych $\mathrm{w}$ gminnym programie (art. 12 ust. 4) oraz zasad wynagradzania członków gminnych komisji rozwiązywania problemów alkoholowych (art. $4^{1}$ ust. 4 i 5), którzy pozostają poza strukturą organizacyjną gminy; czy programu opieki nad zwierzętami bezdomnymi oraz zapobiegania bezdomności zwierząt (art. 11a ustawy o ochronie zwierząt), w szczególności elementy programu dotyczące informacji o miejscu schroniska dla bezdomnych zwierząt, o całodobowej opiece weterynaryjnej, a także postanowienia w zakresie poszukiwania właścicieli dla bezdomnych zwierząt oraz wskazania gospodarstwa rolnego $\mathrm{w}$ celu zapewnienia miejsca dla zwierząt gospodarskich (art. 11a ust. 2 pkt 1, 5, 7 i 8).

Formy prawne aktów planowania jednostek samorządu terytorialnego nie ograniczają się tylko do aktu normatywnego (powszechnie lub wewnętrznie obowiązującego). Są wśród tych planów samorządowych akty administracyjne, w tym decyzja o ustaleniu lokalizacji inwestycji celu publicznego, decyzja o warunkach zabudowy i zagospodarowania terenu (rozdział 5 ustawy o planowaniu i zagospodarowaniu przestrzennym), indywidualne programy wychodzenia $\mathrm{z}$ bezdomności czy usamodzielnienia (art. 49 i 88 ust. 6-7 ustawy z dnia 12 marca 2004 r. o pomocy społecznej ${ }^{42}$ ), a nawet czynności tylko faktyczne (akt planowania ostatecznie jest wprawdzie uchwalany, ale może być wkomponowany w ramy kilku aktów/załączników do aktów albo kilka różnych programów jest ujętych w jednym akcie prawnym), np. program polityki zdrowotnej określany jako „zespół działań” (art. 5 pkt 29a ustawy z dnia 27 sierpnia 2004 r. o świadczeniach opieki zdrowotnej finansowanych ze środków publicznych ${ }^{43}$ ), analizy i studia $\mathrm{z}$ zakresu zagospodarowania przestrzennego prowadzone przez powiat i samorząd województwa (art. 3 ust. 2 i art. 38 ustawy o planowaniu i zagospodarowaniu przestrzennym).

40 Tekst jedn. Dz.U. z 2014 r., poz. 150.

41 Tekst jedn. Dz.U. z 2012 r., poz. 1356 ze zm.

42 Tekst jedn. Dz.U. z 2015 r., poz. 163 ze zm.

43 Tekst jedn. Dz.U. z 2015 r., poz. 581. 


\section{Termin na uchwalenie planu}

Część planów uchwalana jest obligatoryjnie, niektóre z nich - fakultatywnie. Ustawodawca rzadko jednak wyznacza określone konsekwencje za niepodjęcie i niezrealizowanie planu dla organów za to odpowiedzialnych. Najczęściej nie jest wskazany termin na przyjęcie aktu planowania, a jeśli nawet ustawa go określa, nie są zgodnie traktowane skutki prawne uchybienia terminowi na uchwalenie planu.

Nie był jednakowo rozumiany charakter terminu na przyjęcie budżetu, który w zasadzie powinien być podjęty przed rozpoczęciem roku budżetowego, a w szczególnie uzasadnionych przypadkach - nie później niż do dnia 31 stycznia tego roku (art. 239 ustawy z dnia 27 sierpnia 2009 r. o finansach publicznych ${ }^{44}$ ). NSA w wyroku $\mathrm{z}$ dnia 4 listopada $1993 \mathrm{r}$. (SA/Gd 1373/93) ${ }^{45}$ podkreślił, że termin na uchwalenie budżetu jest nieprzekraczalny i jego naruszenie powoduje ustanie kompetencji rady gminy do podjęcia uchwały w sprawie budżetu, a organem umocowanym do ustalenia budżetu staje się regionalna izba obrachunkowa. Podobne stanowisko wyraziła T. Dębowska-Romanowska akcentując jednak przy tym, że w przypadku uchybienia ustawowemu terminowi rada gminy traciłaby uprawnienia do uchwalenia budżetu na okres od 1 do końca lutego, a po tym terminie ponownie je odzyskiwała ${ }^{46}$. Inni autorzy nie podzielali tego stanowiska ${ }^{47}$. Słusznie podniósł szczególnie P. Kryczko, że jeśli rada/sejmik podejmie uchwałę budżetową w lutym, przed ustaleniem budżetu przez regionalną izbę obrachunkową, to nie istnieją już powody do podejmowania przez regionalną izbę obrachunkową czynności zmierzających do jego ustalenia ${ }^{48}$.

Przedmiotem sporu okazał się ponadto charakter terminu na uchwalenie rocznego programu współpracy z organizacjami pozarządowymi oraz gminnego programu opieki nad zwierzętami bezdomnymi oraz zapobiegania bezdomności zwierząt. Pierwszy z tych programów jest uchwalany do dnia 30 listopada roku poprzedzającego okres obowiązywania programu (art. 5a ust. 1 in fine ustawy z dnia 24 kwietnia $2003 \mathrm{r}$.

44 Tekst jedn. Dz.U. z 2013 r., poz. 885 ze zm.

45 ONSA 1994, nr 4, poz. 154.

46 T. Dębowska-Romanowska, Glosa do wyroku NSA z dnia 4 listopada 1993 r., SA/Gd 1373/93, „Monitor Podatkowy” 1994, nr 11, s. 334.

47 M. Kasiński, Glosa do wyroku NSA z 4 listopada 1993 r., SA/Gd 1373/93, „Samorząd Terytorialny” 1994, nr 5, s. 69; P. Kryczko, Finanse samorzqdu województwa, [w:] Komentarz do ustawy o samorządzie województwa, red. P. Chmielnicki, Warszawa 2005, s. 338-339; idem, Gminna gospodarka..., s. 730-731.

48 P. Kryczko, Finanse samorządu..., s. 338-339; idem, Gminna gospodarka..., s. 730. 
o działalności pożytku publicznego i o wolontariacie ${ }^{49}$ ), a drugi - corocznie do dnia 31 marca (art. 11a ust. 1 ustawy o ochronie zwierząt). WSA we Wrocławiu stwierdził, że termin na uchwalenie programu współpracy gminy z organizacjami pozarządowymi ma charakter zawity, a jego uchybienie stanowi istotne naruszenie prawa skutkujące nieważnością całego programu ${ }^{50}$. Innego zdania był NSA określając ten termin jako jedynie instrukcyjny i w efekcie nie rzutujący na ważność uchwały ${ }^{51}$. Taki charakter terminu na uchwalenie akcentowano również $\mathrm{w}$ odniesieniu do programu opieki nad zwierzętami bezdomnymi oraz zapobiegania bezdomności zwierzą ${ }^{52}$.

Gdyby uznać zawity i nieprzywracalny charakter terminu na uchwalenie programu, trzeba byłoby wówczas przyjąć, że przekroczenie tego terminu rodzi skutek $\mathrm{w}$ postaci istotnego naruszenia prawa dającego podstawę do stwierdzenia nieważności uchwały. Wydaje się, że termin na uchwalenie zarówno samorządowych programów współpracy z organizacjami pozarządowymi, jak i gminnego programu opieki nad zwierzętami bezdomnymi oraz zapobiegania bezdomności zwierząt, powinien być rozumiany jako instrukcyjny. $\mathrm{W}$ praktyce i tak już zbyt często pojawiały się przypadki niewykonywania ustawowego obowiązku stanowienia tych aktów. Brak programów w danym roku albo bardzo utrudni, albo nawet uniemożliwi realizację istotnych celów i obowiązków ustawowych polegających na inicjowaniu i rozwoju współpracy z organizacjami pozarządowymi w sferze zadań publicznych czy też na zapewnianiu opieki nad zwierzętami bezdomnymi i ich wyłapywaniu.

Określenie konkretnego terminu na podjęcie uchwały w sprawie programu należałoby interpretować wyłącznie jako świadome działanie dyscyplinujące organy gminy do rozpoczęcia prac nad stworzeniem programu ${ }^{53}$. Nie powinno natomiast - mimo iż jest naruszeniem prawa

49 Tekst jedn. Dz.U. z 2014 r., poz. 1118 ze zm.

50 Zob. wyroki WSA we Wrocławiu: z dnia 4 maja 2011 r., III SA/Wr 112/11, LEX nr 995213; z dnia 19 maja 2011 r., III SA/Wr 142/11, LEX nr 1132856; z dnia 20 maja 2011 r., III SA/Wr 133/11, LEX nr 995216; z dnia 25 maja 2011 r., III SA/Wr 127/11, LEX nr 1100655; z dnia 7 czerwca 2011 r., III SA/Wr 200/11, LEX nr 995222; z dnia 28 czerwca 2011 r., III SA/Wr 221/11, LEX nr 844628; z dnia 29 czerwca 2011 r., III SA/Wr 153/11, LEX nr 1087979; z dnia 6 lipca 2011 r., III SA/Wr 176/11, LEX nr 1154637; z dnia 6 lipca 2011 r., III SA/Wr 228/11, LEX nr 1087985; z dnia 14 lipca 2011 r., III SA/Wr 162/11, LEX nr 1154636; a także rozstrzygnięcie nadzorcze Wojewody Dolnośląskiego z dnia 27 stycznia 2011 r., NK-N.4131.9.2011.LF, LEX nr 786676.

51 Zob. wyroki NSA: $z$ dnia 8 listopada 2011 r., II OSK 1824/11, LEX nr 1212796; z dnia 24 listopada 2011 r., II OSK 2107/11, LEX nr 1152139.

52 Rozstrzygnięcie nadzorcze Wojewody Wielkopolskiego z dnia 31 maja 2012 r., KN.I-4131.2.17.2012.4, LEX nr 1165730.

$53 \mathrm{~J}$. Bobrowicz, Kwalifikacja aktu normatywnego jako aktu prawa miejscowego - na przykładzie uchwały w sprawie programu opieki nad zwierzętami bezdomnymi 
- skutkować nieważnością uchwały w całości. Określone w ustawie obowiązki i wynikająca $\mathrm{z}$ nich odpowiedzialność za współpracę z organizacjami pozarządowymi $\mathrm{w}$ ramach wykonywania określonych zadań czy też za bezdomność zwierząt wymagają nie tylko przygotowania odpowiednich programów, ale przede wszystkim realizacji ich postanowień. Zważywszy na to słuszny jest postulat de lege ferenda, aby ustawodawca dopuścił - w uzasadnionych przypadkach - możliwość uchwalania tych programów w późniejszym terminie ${ }^{54}$.

\section{Instrumenty przeciwdziatania bezczynności planistycznej}

Problemy dotyczące charakteru terminu na uchwalanie planu wiążą się ze szczególnymi środkami nadzoru stosowanymi w razie niepodjęcia aktu. Bezczynność planistyczna polegająca na nieuchwaleniu planu (w sytuacjach istnienia ustawowego obowiązku do podjęcia stosownej uchwały) skutkować będzie - w przypadkach określonych ustawą - ustaleniem planu zastępczego, wydanego przez inny podmiot i w innej formie: organ nadzoru w szczególnym trybie (studium uwarunkowań i kierunków zagospodarowania przestrzennego gminy, budżet), a także przedsiębiorstwo wodociągowo-kanalizacyjne (wieloletni plan rozwoju i modernizacji urządzeń wodociągowych i urządzeń kanalizacyjnych).

Jeżeli rada gminy nie uchwali studium uwarunkowań i kierunków zagospodarowania przestrzennego gminy, nie przystąpi do jego zmiany albo, uchwalając studium, nie określi w nim obszarów rozmieszczenia inwestycji celu publicznego o znaczeniu krajowym i wojewódzkim, ujętych w planie zagospodarowania przestrzennego województwa lub w programach rządowych, wojewoda, po podjęciu czynności zmierzających do uzgodnienia terminu realizacji tych inwestycji i warunków ich wprowadzenia do studium, wzywa radę do uchwalenia studium lub jego zmiany w wyznaczonym terminie. Po bezskutecznym upływie tego terminu wojewoda sporządza miejscowy plan zagospodarowania przestrzennego

i zapobiegania bezdomności zwierzq̨t, „Administracja. Teoria - Dydaktyka - Praktyka” 2012, nr 4, s. 34.

54 Por. J. Kosowski, Komentarz do art. 5a, 5b, 5c ustawy z dnia 24 kwietnia 2003 r. o działalności pożytku publicznego i o wolontariacie (tekst jedn.: Dz.U. z 2010 r. nr 234, poz. 1536 ze zm.), „Przegląd Naukowy Disputatio” 2013, nr 1, s. 117; K. Wlaźlak, Funkcja planowania gminy na przykładzie programu opieki nad zwierzętami bezdomnymi oraz zapobiegania bezdomności zwierząt, „Przegląd Prawa Publicznego” 2015, nr 4, s. 40. 
albo jego zmianę dla obszaru, którego dotyczy zaniechanie gminy, w zakresie koniecznym dla możliwości realizacji inwestycji celu publicznego, wydając w tej sprawie zarządzenie zastępcze wywołujące skutki prawne takie jak miejscowy plan zagospodarowania przestrzennego (art. 12 ust. 3 ustawy o planowaniu i zagospodarowaniu przestrzennym).

Nadzwyczajny środek nadzoru przewidziany został w razie nieuchwalenia budżetów jednostek samorządu terytorialnego oraz ich związków. Regionalna izba obrachunkowa ustala budżet samorządowy w zakresie zadań własnych oraz zadań zleconych w przypadku niepodjęcia uchwały w tej sprawie przez organ stanowiący do dnia 31 stycznia roku budżetowego (art. 11 ust. 2 ustawy z dnia 7 października 1992 r. o regionalnych izbach obrachunko$w \mathrm{ch}^{55}$ ). Ponadto, regionalna izba obrachunkowa ustala budżet w przypadku niezachowania przez jednostkę samorządu terytorialnego zasad określonych $\mathrm{w}$ art. 242-244 ustawy o finansach publicznych, w tym przekroczenia indywidualnego wskaźnika zadłużenia wyliczonego dla danej jednostki.

Specyficzne są również skutki nieuchwalenia wieloletniego planu rozwoju i modernizacji urządzeń wodociągowych i urządzeń kanalizacyjnych, o którym mowa w art. 21 ustawy z dnia 7 czerwca 2001 r. o zbiorowym zaopatrzeniu $\mathrm{w}$ wodę i zbiorowym odprowadzaniu ściekó $\mathrm{w}^{56}$. Plan ten jest opracowywany przez przedsiębiorstwo wodociągowo-kanalizacyjne i przedkładany organowi wykonawczemu gminy. $\mathrm{W}$ razie jego nieuchwalenia przez radę gminy w terminie trzech miesięcy od dnia przedłożenia, plan w takiej formie (opracowany przez przedsiębiorstwo wodociągowo-kanalizacyjne) stanowi podstawę do określenia i jednorazowego zatwierdzenia taryf za pobraną wodę i odprowadzanie ścieków. $\mathrm{W}$ innym przypadku taryfy podlegają zatwierdzeniu w drodze uchwały rady gminy, na wniosek przedsiębiorstwa wodociągowo-kanalizacyjnego.

In genere brakuje sformalizowanych instrumentów przeciwdziałania bezczynności planistycznej. Nie sposób jednak postrzegać możliwości ustalania zastępczych planów inaczej jak tylko wyjątku, szczególnie planów jako aktów nadzoru. Ich istota sprowadza się bowiem do wyłączenia samodzielności planistycznej samorządu terytorialnego. Skoro ustawa explicite nie określa upoważnienia do wprowadzenia ustaleń zastępczych w odniesieniu do pozostałych aktów planowania, nie można byłoby w ich przypadkach domniemywać kompetencji nadzorczych. Możliwość ustanowienia planu w trybie aktu nadzoru w związku z bezczynnością organów jednostek samorządu terytorialnego, polegającą na nieuchwaleniu planu (gdy istnieje ustawowy obowiązek jego podjęcia), powinna być ograniczona tylko do tych przypadków, w których norma prawa wprost upoważnia organ nadzoru do stosowania konkretnych środków.

55 Tekst jedn. Dz.U. z 2012 r., poz. 1113 ze zm.

56 Tekst jedn. Dz.U. z 2015 r., poz. 139. 


\section{Bibliografia}

Bielecki L., Prawne formy i metody dziatania administracji, [w:] Prawo administracyjne. Część ogólna, red. Bielecki L., Ruczkowski P., Warszawa 2011.

Bobrowicz J., Kwalifikacja aktu normatywnego jako aktu prawa miejscowego - na przykładzie uchwaty w sprawie programu opieki nad zwierzętami bezdomnymi i zapobiegania bezdomności zwierząt, „Administracja. Teoria - Dydaktyka - Praktyka" 2012, nr 4.

Dąbek D., Prawo miejscowe, Warszawa 2015.

Dębowska-Romanowska T., Glosa do wyroku NSA z dnia 4 listopada 1993 r., SA/Gd 1373/93, „Monitor Podatkowy" 1994, nr 11.

Dębowska-Romanowska T., Wybrane zagadnienia prawne aktów z zakresu spraw budżetowych - jako przedmiotu nadzoru regionalnych izb obrachunkowych, "Samorząd Terytorialny" 1994, nr 3.

Dziurbejko T., Planowanie rozwoju gminy jako instrument pozyskiwania funduszy pomocowych Unii Europejskiej, Warszawa 2006.

Jaxa Dębicka A., Sprawne państwo. Współczesne koncepcje i instrumenty zarzadzania publicznego a administracja publiczna, Warszawa 2008.

Jeżewski J., 2003, Polityka administracyjna. Zagadnienia podstawowe, [w:] Błaś A., Boć J., Jeżewski J., Administracja publiczna, Wrocław 2003.

Kasiński M., Glosa do wyroku NSA z 4 listopada 1993 r., SA/Gd 1373/93, „Samorząd Terytorialny” 1994, nr 5.

Kasiński M., Monizm i pluralizm władzy lokalnej. Studium prawno-polityczne, Łódź 2009.

Kijowski D.R., Programy, plany i strategie jako podstawa działań organów administracji publicznej, [w:] Wpływ przemian cywilizacyjnych na prawo administracyjne $i$ administrację $p u-$ blicznq, red. Zimmermann J., Suwaj P.J., Warszawa 2013.

Kosowski J., Komentarz do art. 5a, 5b, 5c ustawy z dnia 24 kwietnia $2003 r$. o działalności pożytku publicznego i o wolontariacie (tekst jedn.: Dz.U. z 2010 r. nr 234, poz. 1536 ze zm.), "Przegląd Naukowy Disputatio" 2013, nr 1.

Krawczyk R.P., Nadzór nad działalnościq samorzqdu terytorialnego w Polsce - aktualne problemy, [w:] Regiony w prawie i praktyce. Polska - Ukraina, red. Skotnicki K., Wlaźlak K., Łódź 2015.

Kryczko P., Finanse samorządu województwa, [w:] Komentarz do ustawy o samorzq̨dzie województwa, red. Chmielnicki P., Warszawa 2005.

Kryczko P., Gminna gospodarka finansowa, [w:] Ustawa o samorzqdzie gminnym. Komentarz, red. Chmielnicki P., Warszawa 2013.

Kulesza M., Administracyjnoprawne uwarunkowania polityki przestrzennej, Warszawa 1987.

Leoński Z., Samorzq̨d terytorialny $w R P$, Warszawa 2006.

Ochendowski E., Prawo administracyjne. Część ogólna, Toruń 2013.

Olejniczak-Szałowska E., Tworzenie planów, programów i strategii, [w:] Prawo administracyjne. Pojęcia, instytucje, zasady w teorii i orzecznictwie, red. Stahl M., Warszawa 2013.

Popowska B., Klasyfikacja funkcji administracji w nauce publicznego prawa gospodarczego, [w:] Funkcje wspótczesnej administracji gospodarczej. Księga dedykowana Profesor Teresie Rabskiej, red. Popowska B., Poznań 2006.

Skrzydło-Niżnik I., Model ustroju samorzadu terytorialnego w Polsce na tle zagadnień ustrojowego prawa administracyjnego, Kraków 2007.

Stahl M., Szczególne prawne formy działania administracji, [w:] System 
prawa administracyjnego, Tom 5. Prawne formy działania administracji, red. Hauser R., Niewiadomski Z., Wróbel A., Warszawa 2013.

Strzyczkowski K., Administracyjnoprawne instytucje planowania, Warszawa 1985.

Szewc A., Władze gminy, [w:] Szewc A., Jyż G., Pławecki Z., Ustawa o samorządzie gminnym. Komentarz, Warszawa 2012.

Szydło M., Planowanie indykatywne jako funkcja państwa wobec gospodarki, [w:] Funkcje współczesnej administracji gospodarczej. Księga dedykowana Profesor Teresie Rabskiej, red. Popowska B., Poznań 2006.

Wlaźlak K., Charakter prawny aktów planowania $i$ ich rola $w$ realizacji zadań administracji publicznej, „Przegląd Prawa Publicznego” 2009, nr 6.
Wlaźlak K., Komentarz do art. 18, [w:] Ustawa o samorządzie gminnym. Komentarz, red. Chmielnicki P., Warszawa 2013.

Wlaźlak K., Funkcja planowania gminy na przykładzie programu opieki nad zwierzętami bezdomnymi oraz zapobiegania bezdomności zwierząt, „Przegląd Prawa Publicznego" 2015, $\mathrm{nr} 4$.

Zimmermann J., Aksjomaty prawa administracyjnego, Warszawa 2013.

Zimmermann J., Prawo administracyjne, Warszawa 2014.

Zubik M., Samorzadowa uchwała budżetowa na tle ustrojowych zasad budżetowania. Wybrane problemy legislacyjno-prawne, „Przegląd Legislacyjny” 2003, nr 3. 